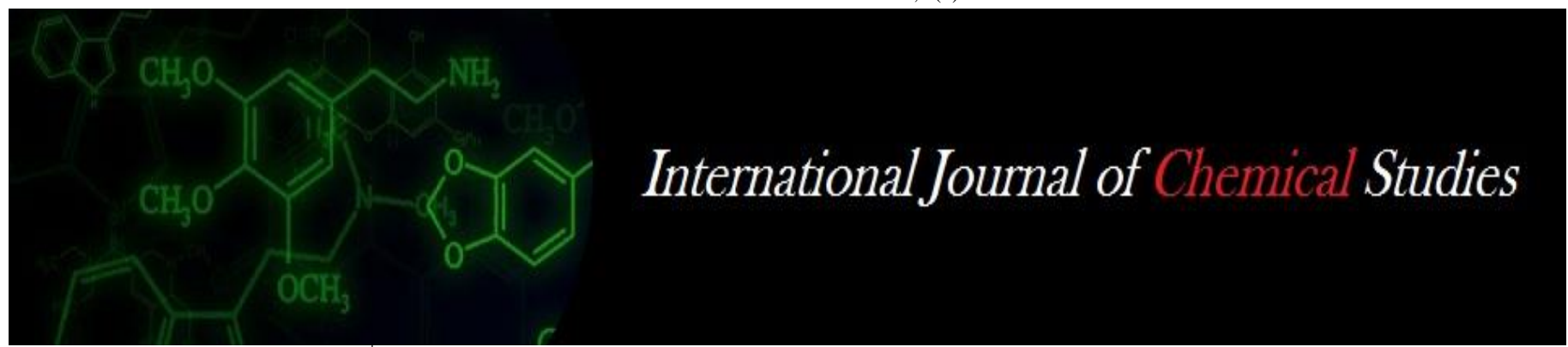

P-ISSN: 2349-8528

E-ISSN: 2321-4902

www.chemijournal.com

IJCS 2021; 9(1): 1907-1910

(C) 2021 IJCS

Received: 04-11-2020

Accepted: 10-12-2020

\section{P Thirumal}

PG Scholar, Agricultural College and Research Institute,

Killikulam, Tamil Nadu, India

\section{Hemalatha M}

Associate Professor, Department of Agronomy, Agricultural

College and Research Institute,

Killikulam, Tamil Nadu, India

\section{Senthil Kumar N}

Assistant Professor, Department of Agronomy, Agricultural

College and Research Institute,

Kudumiyanmalai, Tamil Nadu,

India

\section{Jothimani S}

Professor (SS and AC),

Agricultural College and

Research Institute, Killikulam,

Tamil Nadu, India
Corresponding Author:

P Thirumal

PG Scholar, Agricultural College and Research Institute,

Killikulam, Tamil Nadu, India

\title{
Effect of seedling age and different levels of fertilizer on growth and yield of transplanted finger millet (Eleusine coracana $\mathrm{L}$.)
}

\section{P Thirumal, Hemalatha M, Senthil Kumar N and Jothimani S}

DOI: $\underline{\text { https://doi.org/10.22271/chemi.2021.v9.i1aa.11500 }}$

\begin{abstract}
The experiment was carried out for the evaluation of seedling age and different levels of fertilizer on growth and yield of transplanted finger millet Co (Ra) 15 during rabi season of 2019-2020 at Agricultural College and Research Institute, Killikulam. The experiment was laid in split plot design and replicated thrice. The main plot consists of different age of seedlings viz., 15, 18 and 21 days old seedlings raised with nutrient media. Simultaneously 17 days old seedlings also raised as conventional method. In subplot different levels of recommended fertilizer dose viz., 75, 100 and 125\% were imposed. During the cropping, various plant growth characters such as plant height and drymatter production were recorded at harvest stage and number of tillers hill- ${ }^{-1}$ was recorded at 60 DAT. The yield characters like number of productive tillers, number of earheads $\mathrm{m}^{-2}$, Number of filled grains earhead ${ }^{-1}$, grain and straw yield were also recorded. The experimental result shows that planting 15 days old seedlings from nutrient media along with application of $125 \%$ RDF recorded significantly higher plant height $(108.5 \mathrm{~cm})$, number of tillers hill-1 ${ }^{-1}(8.9)$, drymatter production $\left(9524 \mathrm{~kg} \mathrm{ha}^{-1}\right)$, number of productive tillers hill-1 $(6.9)$, number of earheads $\mathrm{m}^{-2}$ (153), number of filled grains earhead ${ }^{-1}(1696)$, grain $\left(3602 \mathrm{~kg} \mathrm{ha}^{-1}\right)$ and straw yield $\left(6484 \mathrm{~kg} \mathrm{ha}^{-1}\right)$ and it was on par with 15 days old seedlings from nutrient media along with $100 \%$ RDF.
\end{abstract}

Keywords: Finger millet, age of seedlings, fertilizer levels, growth and yield

\section{Introduction}

Finger millet is an important small millet crop in India belongs to the family Poaceae. It is commonly called "Ragi" in India and "Keezhvaragu" in Tamil Nadu. It adds stable diet in human dietary by supplying more health-beneficent nutrients such as carbohydrate, protein, vitamins, fat, crude fibre, calcium, phosphorus, iron, manganese and magnesium compared to other cereals and millets and hence it is called as "nutritious millet" at all over the world (NRC, 1996) ${ }^{[14]}$. The germinated grains contains higher protein, essential amino acid, vitamin A \& B and phosphorus, etc., and had benefits to the pregnant women and children (Gopalan et al., 2004) ${ }^{[7]}$. In India, it occupies the sixth position in production and productivity from the cultivated area of 8.9 lakh hectare with the production and productivity of 12.39 lakh tones and $1390 \mathrm{~kg} \mathrm{ha}^{-1}$, respectively. In Tamil Nadu, the cultivable area under finger millet was 0.79 lakh hectares with a production and productivity of 2.5 lakh tones and $3257 \mathrm{~kg} \mathrm{ha}^{-1}$, respectively during 2018-2019 (Indiastat, 2019) ${ }^{[9]}$.

The productivity of finger millet was registered at low estimates due to transplanting of aged seedlings and improper cultivation practices. In earlier days, the farmers were used their local land races which were long duration and less affected by age of seedling. A number of semidwarf and medium-duration finger millet varieties were evolved and they should be transplanted at the optimum age of seedling for the better return. Transplanting optimum age of seedling produce healthy and vigorous seedlings. Planting of early-stage seedlings and application of the appropriate amount of chemical fertilizers might improve the vegetative growth of the plant, quality of grain and crop yield (Ahiwale et al., 2011) ${ }^{[3]}$. Thus, an attempt was made to find out the effect of age of seedlings produced under different soil media along with levels of nutrients on growth and yield of transplanted finger millet (Eleusine coracana L.). 


\section{Materials and Methods}

The field experiment was conducted at Agricultural College and Research Institute, Killikulam during rabi season of 2019-2020. Finger millet Co (Ra) 15 variety was used for this experiment to ascertain the effect of age of seedlings and different levels of fertilizer on growth and yield of transplanted finger millet. The soil was sandy clay loam in nature. The field experiment was laid out in split plot design and replicated thrice. The main plot consists of four different age of seedlings viz., 15, 18 and 21 days old seedlings raised from nutrient media (soil $(70 \%)+$ well decomposed FYM $(20 \%)+$ rice hull $(10 \%)+$ DAP @ 7 g/tray + Azophos @ 14 $\mathrm{g} /$ tray + vermicompost @100 g/tray - with a tray size of $60 \times$ $30 \mathrm{~cm}$ ) and simultaneously 17 days old seedlings also raised from conventional method. In subplot, three levels of RDF viz., 75, 100 and $125 \%$ were used. The recommended dose of fertilizer was 60:30:30 kg NPK ha-1 . Observation like plant height and dry matter production were recorded at harvest stage and number of tillers hill ${ }^{-1}$ was recorded at $60 \mathrm{DAT}$. The yield attributes like number of productive tillers, earheads $\mathrm{m}^{-2}$, number of filled grains earhead ${ }^{-1}$ and yield of grain and straw were recorded.

\section{Results and Discussion}

Growth parameters: The growth parameters viz., plant height, number of tillers hill ${ }^{-1}$ and dry matter production were diversely influenced by different age of seedlings and levels of fertilizer used. Transplanting of 15 days old seedlings from nutrient media registered higher plant height $(103.4 \mathrm{~cm})$, number of tillers hill ${ }^{-1}$ (8.4) and dry matter production (8834 $\mathrm{kg} \mathrm{ha}^{-1}$ ) and it was statistically on par with 18 days old seedlings raised from nutrient media recorded the plant height $(98.3 \mathrm{~cm})$, number of tillers (7.9) and dry matter production $\left(8313 \mathrm{~kg} \mathrm{ha}^{-1}\right.$ ) (Table 1). The higher growth parameters achieved from the above treatments might be due to the seedlings took lesser number of days for transplanting shock and greater number of primary and secondary roots in younger seedlings. These active roots helped in higher uptake of nutrients at an early stage of crop growth led to increased growth parameters. This result was similar with Ramachandra et al. $(2012)^{[16]}$. Whereas 21 days old seedlings from nutrient media recorded lesser plant height $(85.9 \mathrm{~cm})$, number of tillers (5.9) and dry matter production (7277 $\left.\mathrm{kg} \mathrm{ha}^{-1}\right)$. Planting of 17 days old seedlings from conventional method performed equally with 18 days old seedlings raised from nutrient media on growth parameters of ragi.

Table 1: Effect of age of seedlings and different levels of fertilizer on growth characters of transplanted finger millet

\begin{tabular}{|c|c|c|c|c|c|c|c|c|c|c|c|c|c|c|}
\hline \multicolumn{5}{|c|}{ Plant height (cm) } & \multicolumn{5}{|c|}{ No. of tiller hill ${ }^{-1}$} & \multicolumn{5}{|c|}{ Dry matter production $\left(\mathrm{kg} \mathrm{ha}^{-1}\right)$} \\
\hline & S1 & S2 & $\mathbf{S 3}$ & Mean & & S1 & S2 & S3 & Mean & & S1 & $\mathbf{S 2}$ & S3 & Mean \\
\hline M1 & 86.7 & 94.7 & 97.3 & 92.9 & M1 & 6.6 & 7.5 & 8.0 & 7.4 & M1 & 7453 & 7863 & 8392 & 7903 \\
\hline M2 & 98.6 & 103.2 & 108.5 & 103.4 & M2 & 7.8 & 8.4 & 8.9 & 8.4 & M2 & 7853 & 9126 & 9524 & 8834 \\
\hline M3 & 93.9 & 98.7 & 102.3 & 98.3 & M3 & 7.5 & 8.1 & 8.2 & 7.9 & M3 & 7604 & 8437 & 8897 & 8313 \\
\hline M4 & 77.7 & 88.2 & 91.7 & 85.9 & M4 & 5.2 & 5.9 & 6.7 & 5.9 & M4 & 6641 & 7352 & 7838 & 7277 \\
\hline Mean & 89.2 & 96.2 & 100.0 & & Mean & 6.8 & 7.5 & 8.0 & & Mean & 7388 & 8195 & 8663 & \\
\hline & M & $\mathbf{S}$ & M at $S$ & S at $M$ & & M & $\mathbf{S}$ & $M$ at $S$ & S at $M$ & & M & $\mathbf{S}$ & M at $\mathbf{S}$ & S at $M$ \\
\hline S.Ed & 3.1 & 3.1 & 3.0 & 2.6 & S.Ed & 0.3 & 0.3 & 0.2 & 0.2 & S.Ed & 259 & 255 & 267 & 227 \\
\hline $\mathrm{CD}(p=0.05)$ & 6.6 & 6.5 & 6.4 & 5.4 & $\mathrm{CD}(p=0.05)$ & 0.7 & 0.6 & 0.5 & 0.4 & $\mathrm{CD}(p=0.05)$ & 550 & 540 & 566 & 481 \\
\hline
\end{tabular}

With regard to different levels of fertilizer, application of $125 \%$ RDF was recorded higher plant height $(100.0 \mathrm{~cm})$, number of tillers (8.0) and dry matter production $(8663 \mathrm{~kg} \mathrm{ha}$ $\left.{ }^{1}\right)$. However, it was on par with $100 \%$ RDF produced the plant height of $96.2 \mathrm{~cm}$, number of tillers hill ${ }^{-1}$ of 7.5 and dry matter production of $8195 \mathrm{~kg} \mathrm{ha}^{-1}$. This might be due to higher dosage of fertilizers that increased the uptake of nutrients eventually increased the growth contributing characters of finger millet (Manjunatha et al., 2010) ${ }^{[11]}$. The minimum growth parameters were observed with $75 \%$ RDF.

On interaction, age of seedlings and levels of inorganic fertilizer were significantly influenced the growth parameters of finger millet. Transplanting of 15 days old seedlings from nutrient media along with application of $125 \%$ RDF showed maximum plant height $(108.5 \mathrm{~cm})$ number of tillers $(8.9)$ and dry matter production $\left(9524 \mathrm{~kg} \mathrm{ha}^{-1}\right)$ and it was on par with 15 days old seedlings along with $100 \%$ RDF. This might be due to profuse rooting ability of young seedlings, maximum utilization of nutrients and other resources effectively at early stages resulted in higher growth characters. This similar results were confirmed with Kumar et al. (2019) ${ }^{[16]}$. Transplanting of 21 days old seedlings coupled with $75 \%$ RDF registered lesser plant height $(77.7 \mathrm{~cm})$, number of tillers hill $^{-1}(5.2)$ and dry matter production $\left(6641 \mathrm{~kg} \mathrm{ha}^{-1}\right)$. Aged seedlings and heavy root damage occurred at the time of uprooting of seedlings resulted in more time for recovery and less availability of nutrients might be the reason for getting lesser growth characters (Singh et al., 2018) ${ }^{[17]}$.

\section{Yield attributes}

Yield attributes like number of productive tillers, earheads $\mathrm{m}^{-2}$ and filled grains earhead ${ }^{-1}$ were significantly influenced by different age of seedlings and levels of fertilizer used. With respect to age of seedlings, maximum number of productive tillers (6.5), earheads $\mathrm{m}^{-2}(140)$ and number of filled grains earheads $^{-1}$ (1512) were obtained from transplanting of 15 days old seedlings raised under nutrient media and it was on par with 18 days old seedlings recorded 6.2 productive tillers hill 1 , earheads $\mathrm{m}^{-2}(127)$ and number of filled grains earhead ${ }^{-1}$ (1403) (Table 2). This might be due to lesser transplanting shock period and greater establishment of plants with more growth characters resulted in higher yield attributes. Similar findings were reported by Anitha (2015) ${ }^{[4]}$ and Manjunatha et al. (2010) ${ }^{[11]}$. The minimum number of yield attributes were recorded with 21 days old seedlings. Transplanting of 17 days old seedlings from conventional method equally produced yield attributes as that of 18 days old seedlings raised from nutrient media. 
Table 2: Effect of age of seedlings and different levels of fertilizer on yield attributes of transplanted finger millet

\begin{tabular}{|c|c|c|c|c|c|c|c|c|c|c|c|c|c|c|}
\hline \multicolumn{5}{|c|}{ Productive tillers hill ${ }^{-1}$} & \multicolumn{5}{|c|}{ Earheads $\mathbf{m}^{-2}$} & \multicolumn{5}{|c|}{ Filled grains earhead $^{-1}$} \\
\hline & S1 & S2 & S3 & Mean & & S1 & S2 & S3 & Mean & & S1 & S2 & S3 & Mean \\
\hline M1 & 5.3 & 5.8 & 6.2 & 5.8 & M1 & 109 & 119 & 126 & 118 & M1 & 1103 & 1378 & 1452 & 1311 \\
\hline M2 & 6.1 & 6.6 & 6.9 & 6.5 & M2 & 123 & 145 & 153 & 140 & M2 & 1236 & 1603 & 1696 & 1512 \\
\hline M3 & 5.8 & 6.3 & 6.4 & 6.2 & M3 & 115 & 127 & 138 & 127 & M3 & 1183 & 1468 & 1557 & 1403 \\
\hline M4 & 4.5 & 5.1 & 5.5 & 5.0 & M4 & 90 & 105 & 116 & 104 & M4 & 1017 & 1136 & 1223 & 1125 \\
\hline Mean & 5.4 & 5.9 & 6.3 & & Mean & 109 & 124 & 133 & & Mean & 1135 & 1396 & 1482 & \\
\hline & $\mathbf{M}$ & $\mathbf{S}$ & $M$ at $S$ & S at M & & $\mathbf{M}$ & $\mathbf{S}$ & $\mathrm{M}$ at $\mathrm{S}$ & S at $\mathrm{M}$ & & $\mathbf{M}$ & $\mathbf{S}$ & $M$ at $S$ & S at $\mathrm{M}$ \\
\hline S.Ed & 0.2 & 0.2 & 0.2 & 0.2 & S.Ed & 6 & 6 & 4 & 3 & S.Ed & 52 & 50 & 47 & 40 \\
\hline $\mathrm{CD}(p=0.05)$ & 0.5 & 0.4 & 0.4 & 0.3 & $\mathrm{CD}(p=0.05)$ & 13 & 12 & 9 & 7 & $\mathrm{CD}(p=0.05)$ & 110 & 106 & 99 & 84 \\
\hline
\end{tabular}

Likewise, application of $125 \%$ RDF recorded higher number of productive tillers (6.3), earheads $\mathrm{m}^{-2}$ (133) and number of filled grains earhead ${ }^{-1}(1482)$ and it was on par with the recommended dose of fertilizer. This maximum yield attributes observed in the said treatments might be due to enlargement of cell, stem elongation, more number of functional leaves which occurred as an outcome of enhanced level of nutrients led to increased growth parameters resulted in higher photosynthetic activity and grater accumulation of photosynthates into sink. Similar findings were reported by Abhishek and Avudaithai (2018) ${ }^{[1]}$. The minimum number of productive tillers (5.4), earheads $\mathrm{m}^{-2}$ (109) and number of filled grains earhead ${ }^{-1}(1135)$ was obtained with application of $75 \%$ RDF.

Transplanting of 15 days old seedlings from nutrient media along with $125 \%$ RDF recorded maximum number of productive tillers (6.9), earheads $\mathrm{m}^{-2}$ (153) and number of filled grains earhead ${ }^{-1}(1696)$. It was on par with transplanting of 15 days old seedlings raised from nutrient media coupled with $100 \%$ RDF. This might be due to transplanting of younger age seedlings with application of higher dose of fertilizer supported with strong root system, higher number of tillers and increased plant metabolism led to increased yield contributing characters. These findings have also been confirmed by Nevse et al. (2013) ${ }^{[13]}$. Transplanting of 21 days old seedlings with application of $75 \%$ RDF was recorded lesser number of productive tillers (4.5), earheads $\mathrm{m}^{-2}(90)$ and number of filled grains earhead ${ }^{-1}(1017)$. Minimum yield attributing traits resulting from less uptake and translocation of nutrients in older seedlings (Fahad et al., 2015) ${ }^{[6]}$.

\section{Grain and straw yield}

Grain and straw yield were greatly influenced by different age of seedlings and levels of fertilizer. Maximum grain $(3267 \mathrm{~kg}$ $\left.\mathrm{ha}^{-1}\right)$ and straw yield (6001 $\left.\mathrm{kg} \mathrm{ha}^{-1}\right)$ were recorded with transplanting of 15 days old seedlings raised from nutrient media and it was on par with transplanting of 18 days old seedlings from nutrient media registered grain and straw yield of 3061 and $5676 \mathrm{~kg} \mathrm{ha}^{-1}$, respectively (Table 3). This might be due to planting of younger seedlings produced maximum growth and yield parameters which was resulted in higher grain and straw yield of finger millet (Adhikari et al., 2013 ${ }^{[2]}$, Chaudhari et al., 2015) ${ }^{[5]}$. The minimum grain $\left(2709 \mathrm{~kg} \mathrm{ha}^{-1}\right)$ and straw yield $\left(5129 \mathrm{~kg} \mathrm{ha}^{-1}\right)$ were obtained by transplanting of 21 days old seedlings. Whereas, transplanting of 17 days old seedlings raised from conventional method similarly reacted on the yield of finger millet as that of 18 days old seedlings raised from nutrient media.

Table 3: Effect of age of seedlings and different levels of fertilizer on grain and straw yield of transplanted finger millet

\begin{tabular}{|c|c|c|c|c|c|c|c|c|c|}
\hline \multicolumn{5}{|c|}{ Grain yield $\left(\mathrm{kg} \mathrm{ha}^{-1}\right)$} & \multicolumn{5}{|c|}{ Straw yield $\left(\mathrm{kg} \mathrm{ha}^{-1}\right)$} \\
\hline & S1 & S2 & S3 & Mean & & S1 & S2 & S3 & Mean \\
\hline M1 & 2654 & 3048 & 3176 & 2959 & M1 & 5123 & 5549 & 5789 & 5487 \\
\hline M2 & 2803 & 3397 & 3602 & 3267 & M2 & 5329 & 6191 & 6484 & 6001 \\
\hline M3 & 2708 & 3162 & 3314 & 3061 & M3 & 5225 & 5746 & 6058 & 5676 \\
\hline M4 & 2485 & 2723 & 2918 & 2709 & M4 & 4752 & 5207 & 5427 & 5129 \\
\hline Mean & 2663 & 3083 & 3253 & & Mean & 5107 & 5673 & 5940 & \\
\hline & M & $\mathbf{S}$ & M at S & S at $M$ & & M & $\mathbf{S}$ & M at $S$ & S at $M$ \\
\hline S.Ed & 104 & 101 & 100 & 85 & S.Ed & 160 & 157 & 186 & 158 \\
\hline $\mathrm{CD}(p=0.05)$ & 220 & 215 & 213 & 181 & $\mathrm{CD}(p=0.05)$ & 340 & 333 & 393 & 334 \\
\hline
\end{tabular}

Application of $125 \% \mathrm{RDF}$ recorded higher grain $(3253 \mathrm{~kg} \mathrm{ha}$ ${ }^{1}$ ) and straw yield $\left(5940 \mathrm{~kg} \mathrm{ha}^{-1}\right)$. However, it was on par with the application of $100 \%$ RDF. This might be due to better growth parameters resulting from maximum uptake of nutrients which was reflected in higher yield attributing characters and finally resulted in higher grain and straw yield (Hussain et al., 2012, Narayan and Ramachandrappa, 2017) ${ }^{[6,}$ ${ }^{8,12]}$. The lesser grain $\left(2663 \mathrm{~kg} \mathrm{ha}^{-1}\right)$ and straw yield $(5107 \mathrm{~kg}$ $\mathrm{ha}^{-1}$ ) were recorded with application of $75 \%$ RDF.

On interaction effect, maximum grain (3602 $\left.\mathrm{kg} \mathrm{ha}^{-1}\right)$ and straw yield $\left(6484 \mathrm{~kg} \mathrm{ha}^{-1}\right)$ were registered when transplanting of 15 days old seedlings raised from nutrient media along with $125 \%$ of recommended dose of fertilizer. However, it was on par with transplanting of 15 days old seedlings combined with $100 \%$ RDF. This might be due to younger seedlings that develop their roots rapidly because of lesser transplanting shock and minimal root damage during transplanting resulted in the absorption of higher nutrients from the soil than the older seedlings. It promoted the growth characters and yield attributes which resulted in higher grain and straw yield of finger millet. The lesser grain $\left(2485 \mathrm{~kg} \mathrm{ha}^{-}\right.$ $\left.{ }^{1}\right)$ and straw yield (4752 $\left.\mathrm{kg} \mathrm{ha}^{-1}\right)$ were obtained with 21 days old seedlings along with application of lesser recommended dose of fertilizer (75\%). Similar findings were reported by Pramanik and Bera (2013) ${ }^{[15]}$ and Nevse et al. (2013) ${ }^{[13]}$.

\section{Conclusion}

From the investigation it could be concluded that, planting 15 days old seedlings raised from nutrient media along with application of $125 \%$ RDF recorded higher growth, yield attributes, grain and straw yield of transplanted finger millet and it was on par with transplanting of 15 days old seedlings 
raised from nutrient media with $100 \%$ RDF. Thus, the study recommended that transplanting of 15 days old seedlings raised from nutrient media with $100 \%$ RDF was the best management practices to get higher yield in transplanted finger millet.

\section{References}

1. Abhishek MJ, Avudaithai S. Effect of Different Levels of NPK on Yield and Nutrient Uptake of Finger Millet Varieties under Sodic Soil Condition. Research journal of Agricultural Sciences 2018;9(6):1215-1218.

2. Adhikari, Bishnu Bilas, Biswarup Mehera, Haefele SM. Impact of rice nursery nutrient management, seeding density and seedling age on yield and yield attributes. American Journal of Plant Sciences 2013;4:146-155.

3. Ahiwale PH, Chavan LS, Jagtap DN, Mahadkar UV, Gawade MB. Effect of establishment methods and nutrient management on yield attributes and yield of finger millet (Eleusine coracana G.). Adv. Res. J Crop Improv 2011;2:247-250.

4. Anitha Doddi. Finger millet [Eleusine coracana (L.) Gaertn] productivity as influenced by crop geometry and age of seedlings. M. Sc. (Ag.) Thesis, ANGRAU, Hyderabad 2015.

5. Chaudhari PR, Patel AP, Patel VP, Desai LJ, Patel JV, Chaudhari DR, Tandel DH. Effect of age of seedlings and fertilizer management on yield, nutrient content and uptake of rice (Oryza Sativa L.). The Bioscan 10 2015;(1):351-353.

6. Fahad, Shah, Saddam Hussain, Amar Matloob, Faheem Ahmed Khan, Abdul Khaliq, Shah Saud, Shah Hassan, Darakh Shan, Fahad Khan, Najeeb Ullah. Phytohormones and plant responses to salinity stress: a review. Plant growth regulation 2015;75(2):391-404.

7. Gopalan C, RamaSastri BV, Balasubramanian SC. Nutritive value of Indian foods (Revised and updated, Narasinga Rao BS, Deosthale YG and Pant KC). ICARNational Institute of Nutrition, Hyderabad 2004.

8. Hussain A, Bhat MA, Ganie MA. Effect of number and age of seedlings on growth, yield, nutrient uptake and economics of rice (Oryza sativa) under system of rice intensification in temperate conditions. Indian Journal of Agronomy 2012;57(2):133-137.

9. Indiastat. Indiastat: Socio-Economic Statistical Data 2019.

10. Kumar, Dibbagandla Prasanna, Sagar Maitra, Tanmoy Shankar. Growth, Yield and Quality of Finger Millet (Eleusine coracana L. Gaertn) as Influenced by Crop Geometry and Age of Seedlings. IJBS 2019;6(2):75-79.

11. Manjunatha BN, Basavarajappa R, Pujari BT. Effect of age of seedlings on growth, yield and water requirement by different system of rice intensification. Karnataka Journal of Agricultural Sciences 2010;23(2):231-234.

12. Narayan, Hebbal, Ramachandrappa BK. Effect of method of establishment, planting geometry and nutrient source on growth and yield of finger millet (Eleusine coracana L.). Mysore Journal of Agricultural Sciences 2017;51(2):392-396.

13. Nevse GP, Chavan LS, Jagtap DN. Performance of Finger millet (Eleusine coracana [L.] Gaertn) to age of seedlings, FYM and fertilizer levels. J Indian Soc. Coastal agric. Res 2013;31(2):64-70.

14. NRC, National Research Council. Lost Crops of Africa. Vol. I: Grains. Board of Science and Technology for
International Development. National Academy Press Washington, DC 1996.

15. Pramanik K, Bera AK. Effect of seedling age and nitrogen fertilizer on growth, chlorophyll content, yield and economics of hybrid rice (Oryza sativa L.). International Journal of Agronomy and Plant Production 2013;4(5):3489-3499.

16. Ramachandra C, Shivakumar N, Rajanna MP, Kalyanamurthy KN. Effect of age of seedlings and weed management under SRI on yield of rice. Indian J Weed Sci 2012;44:50-52.

17. Singh, Teekam, Satapathy BS, Pun KB. Influence of seeding density on seedling growth, productivity and profitability of rice (Oryza sativa) under rainfed lowland. Indian Journal of Agronomy 2018;63(1):55-59. 